EXTENDED REPORT

\title{
Relationship between serum trough infliximab levels, pretreatment $C$ reactive protein levels, and clinical response to infliximab treatment in patients with rheumatoid arthritis
}

\author{
G J Wolbink, A E Voskuyl, W F Lems, E de Groot, M T Nurmohamed, P P Tak, \\ B A C Dijkmans, L Aarden
}

See end of article for authors' affiliations

Correspondence to: Dr G J Wolbink, Dr Jan van Breemenstraat 2, $1056 \mathrm{AB}$ Amsterdam, The Netherlands; g.wolbink@ janvanbreemen.nl

Accepted

7 September 2004

Published Online First

14 October 2004

\begin{abstract}
Objective: To investigate the relationship between serum trough infliximab levels and clinical response to infliximab treatment in patients with rheumatoid arthritis (RA).

Methods: Disease activity and serum trough infliximab levels before and 2, 6, and 14 weeks after initiation of infliximab treatment at a dose of $3 \mathrm{mg} / \mathrm{kg}$ in a cohort of 105 patients with RA were assessed. Serum trough infliximab levels in responders and non-responders were compared. Additionally, the clinical responses of patients with high, intermediate, and low serum trough infliximab levels at 14 weeks were compared.

Results: After 14 weeks of treatment non-responders had lower serum trough levels of infliximab than responders (median (interquartile range) $0.5(0.2-2.2)$ v $3.6(1.4-8.2) \mathrm{mg} / \mathrm{l} ; \mathrm{p}<0.01))$. Patients with low serum trough infliximab levels at 14 weeks had significantly less improvement in the 28 joint count Disease Activity Score (DAS28) score than patients with intermediate or high serum trough infliximab levels at 14 weeks. Pretreatment $C$ reactive protein (CRP) levels correlated negatively with serum trough infliximab levels at 14 weeks affer the start of treatment (Spearman rank correlation $r_{s}=-0.43, p<0.001$ ).

Conclusion: Serum trough levels of infliximab correlate with the clinical response to treatment with infliximab and pretreatment CRP levels. This study indicates that patients with high pretreatment CRP levels might benefit from higher dosages of infliximab or shorter dosing intervals.
\end{abstract}

$\mathrm{T}$ he efficacy of infliximab as a treatment for patients with active rheumatoid arthritis (RA) has been demonstrated in randomised controlled trials. ${ }^{12}$ Currently many patients with active RA despite methotrexate (MTX) treatment receive a standardregimenofinfliximabthatconsistsofa $3 \mathrm{mg} / \mathrm{kginfusion}$ at 0,2 , and 6 weeks and every 8 weeks thereafter. ${ }^{3}$ However, despite treatment with infliximab, many patients have persistent disease activity and some patients do not even reach response criteria. It might be suggested that in such patients tumour necrosis factor (TNF) is not completely neutralised owing to insufficient dosing with infliximab.

The optimal dosing regimen for infliximab is still unknown. A comparison of response rates across infliximab treatment groups in the ATTRACT study indicated a doseresponse relationship. Moreover, post hoc analysis of data from the ATTRACT study provided evidence for a significant relationship between the extent of clinical improvement and trough serum concentrations of infliximab. ${ }^{5}$ Two recent studies showed that intensification of treatment in nonresponders may lead to a significant decrease in the mean Disease Activity Score (DAS). ${ }^{6}$ A better understanding of the relationship between disease activity and serum infliximab levels may lead to more effective use of this treatment.

Therefore, we developed an assay for the detection of infliximab in sera and used this to analyse the relationship between clinical improvement and serum trough infliximab levels in patients with RA after 14 weeks of treatment with the standard regimen of $3 \mathrm{mg} / \mathrm{kg}$.

\section{PATIENTS AND METHODS}

Patients

One hundred and five consecutive patients with RA receiving infliximab treatment were included in this open, prospective, observational study. Patients were enrolled at the departments of rheumatology of the Slotervaart Hospital and the VU Medical Centre in Amsterdam from April 2000 to January 2002. Patients were included according to the consensus statement on the initiation and continuation of TNF blocking treatments in RA. All patients fulfilled the American College of Rheumatology 1987 revised criteria for $\mathrm{RA}^{8}$ and all had evidence of active disease, as indicated by a Disease Activity Score in 28 joints $($ DAS28 $=0.56 \sqrt{ }($ tender joints 28) + $0.28 \sqrt{ }($ swollen joints 28$)+0.70 \ln ($ ESR $)+0.014$ (general health on a visual analogue scale) of $>3.2$ despite earlier MTX treatment at a dose of $25 \mathrm{mg}$ weekly or at the maximum tolerable dose. ${ }^{4}{ }^{9}$

All patients were given intravenous infusions of $3 \mathrm{mg} / \mathrm{kg}$ of infliximab at weeks $0,2,6$, and 14. Concomitant stable drug treatment, including MTX treatment, was continued. Disease activity was assessed before each infusion (at weeks 0, 2, 6, and 14) using the DAS28 score. In addition, serum samples were collected before each infusion for the assessment of serum infliximab levels and serum $C$ reactive protein (CRP) concentration.

\section{Measurement of serum infliximab levels}

Infliximab levels were determined by enzyme linked immunosorbent assay (ELISA). Briefly, a mouse monoclonal antibody directed against TNF (CLB TNF/7) was coated overnight at room temperature $(2 \mu \mathrm{g} / \mathrm{ml}$ in $100 \mu \mathrm{l}$ well $)$ on flat bottomed microtitre plates. Recombinant TNF

Abbreviations: CRP, $C$ reactive protein; DAS28, 28 joint Disease Activity Score; ELISA, enzyme linked immunosorbent assay; ESR, erythrocyte sedimentation rate; MTX, methotrexate; RA, rheumatoid arthritis; TNF, tumour necrosis factor 


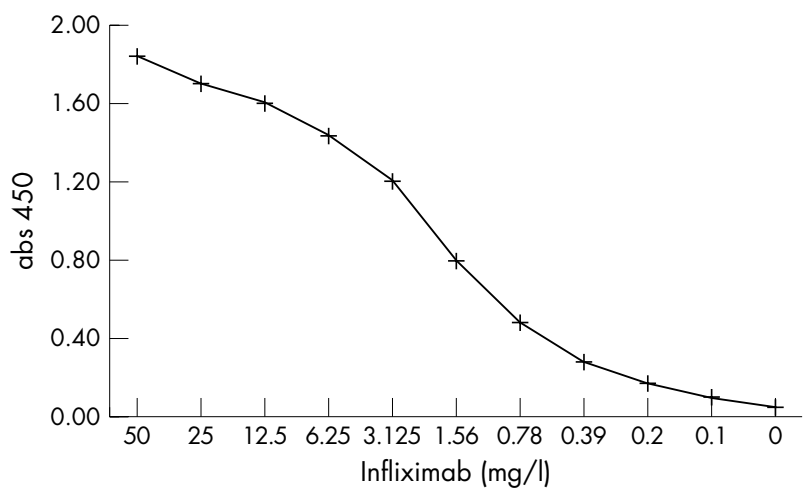

Figure 1 Standard curve of infliximab in the ELISA.

$(0.1 \mu \mathrm{g} / \mathrm{ml}$ in a $100 \mu \mathrm{l}$ well) in HPE buffer (CLB BIR, Amsterdam, The Netherlands) was added for 1 hour. After washing with phosphate buffered saline/0.2\% Tween, patients' serum samples were added in different dilutions in high performance ELISA (HPE) buffer and incubated for 2 hours at room temperature. Plates were washed with phosphate buffered saline/0.2\% Tween, then incubated with horseradish peroxidase conjugated monoclonal anti human IgG (MH16) in $100 \mu \mathrm{l} \mathrm{HPE} \mathrm{buffer} \mathrm{for} 1$ hour at room temperature. Subsequently, after washing, tetramethylbenzidine was added. The reaction was stopped with $2 \mathrm{M}$ $\mathrm{H}_{2} \mathrm{SO}_{4}$. Absorption at $450 \mathrm{~nm}$ was then determined in a multiscan (Multiskan; Titertek, Elfab Oy, Finland). Results were related to a titration curve of infliximab in each plate. The lowest level of detection was $0.2 \mathrm{mg} / \mathrm{l}$. Figure 1 shows a dose-response curve. The ELISA thus captures infliximab through its ability to bind to TNF $\alpha$. It does not bind immune complexes consisting of infliximab and TNF or infliximab bound by neutralising antibodies.

Serum CRP levels were assessed by immunonephelometry and used as an indirect marker for TNF production.

\section{Statistical analysis}

Patients were classified as responders/non-responders at 14 weeks according to the EULAR response criteria. Nonresponse was defined as a DAS28 decrease after 14 weeks of $\leqslant 0.6$, or a decrease $>0.6$ and $\leqslant 1.2$ with an attained DAS of $>5.1$.

The relationship between serum infliximab levels and clinical response was further analysed by categorising patients into tertiles according to their infliximab level at 14 weeks. The relationship of pretreatment CRP levels and clinical response was analysed by categorising patients into tertiles according to their pretreatment CRP level.

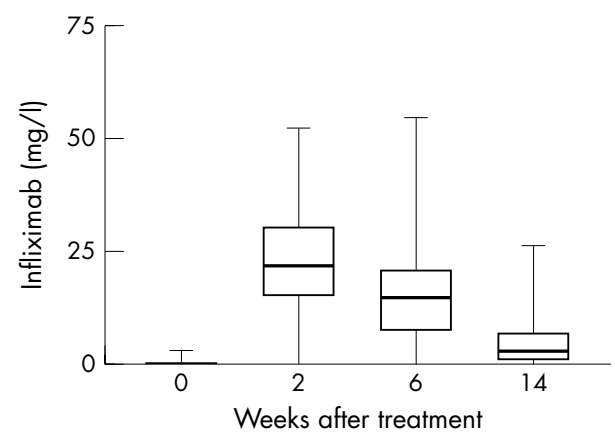

Figure 2 Serum trough infliximab levels in 105 patients treated with $3 \mathrm{mg} / \mathrm{kg}$ infliximab. Data are shown as box-whisker plots, representing the median, 25th and 75 th centile, and range.

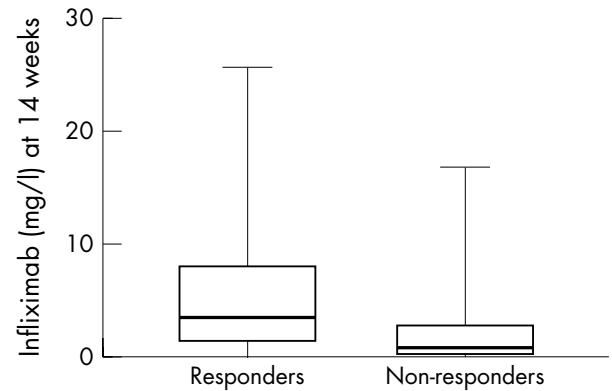

Figure 3 Serum trough infliximab levels in patients with RA treated with infliximab according to clinical response at 14 weeks.

Different groups were compared by the Mann-Whitney test or a two-sided Kruskal-Wallis non-parametric test. The Spearman rank test was used for correlations between variables. The threshold for significance was set at $\mathrm{p}<0.05$.

\section{RESULTS}

\section{Baseline characteristics of patients}

The majority of patients who entered the study were women $(82 \%)$, with a mean (SD) age of 56 (13) years, and a mean (SD) disease duration of 12 (9) years. Seventy per cent of the patients had tested positive for rheumatoid factor. The mean number of disease modifying antirheumatic drugs used before infliximab treatment was 3.7. Eighty six patients used concomitant methotrexate with a mean dosage of $14 \mathrm{mg}$ every week. At study entry patients had active disease despite MTX treatment, as indicated by a mean (SD) DAS28 score of 6.1 (1.3). (Mean (SD) erythrocyte sedimentation rate (ESR) 40 (25), mean (SD) general health 65 (20), mean (SD) swollen joint count $13(6)$, mean (SD) tender joint count 13 (8).)

\section{Clinical response}

After 14 weeks of treatment the mean DAS28 score improved from 6.1 to 4.3 . Seventy seven $(73 \%)$ patients fulfilled the EULAR response criteria.

\section{Serum infliximab levels}

After 2 weeks the median (interquartile range) serum trough infliximab level was 22.3 (15.3-29.4) $\mathrm{mg} / \mathrm{l}$, after a 4 week interval $14.6(7.3-22) \mathrm{mg} / \mathrm{l}$, and after 8 weeks 2.8 (0.66.8) $\mathrm{mg} / \mathrm{l}$. Serum trough infliximab levels showed considerable variation between patients (fig 2). Remarkably, serum infliximab levels were below the detection limit in the three serum samples that were collected before all three infusions that induced an allergic reaction.

After 14 weeks of treatment responders had significantly $(\mathrm{p}<0.01)$ higher median serum trough infliximab concentrations than non-responders (3.6 (1.4-8.2) v $0.5(0.2-2.2) \mathrm{mg} / \mathrm{l}$; fig 3 ). With multivariate regression analysis the association between clinical response and serum trough infliximab levels at 14 weeks was confirmed. The association between clinical response and serum trough infliximab remained significant after correction for potential confounders such as baseline CRP, baseline DAS28 score, and rheumatoid factor (data not shown).

To analyse further the relationship between serum infliximab levels and clinical response, patients were categorised into three groups according to their infliximab level at 14 weeks. Table 1 shows the results obtained. Patients categorised as having low serum trough infliximab levels at 14 weeks less often fulfilled the EULAR response criteria (50\% v 90\% and 88\%) and had significantly less improvement in the DAS28 score between 1 and 14 weeks $(-0.9 v-2.0$ 
Table 1 Clinical response of patients with low, intermediate, and high serum trough infliximab levels at 14 weeks

\begin{tabular}{|c|c|c|c|c|}
\hline \multirow[b]{2}{*}{ Clinical response } & \multicolumn{3}{|c|}{ Serum trough infliximab levels at 14 weeks } & \multirow[b]{2}{*}{ Significance } \\
\hline & $\begin{array}{l}\text { Low } \\
\text { (0-1.2 mg/l) }\end{array}$ & $\begin{array}{l}\text { Intermediate } \\
\text { (1.3-4.7 mg/l) }\end{array}$ & $\begin{array}{l}\text { High } \\
(5.0-25.8 \mathrm{mg} / \mathrm{l})\end{array}$ & \\
\hline Mean DAS28, $t=0$ & 6.4 & 6.1 & 5.8 & NS \\
\hline Mean $C R P, t=0$ & 49 & 29 & 17 & * \\
\hline EULAR responders (\%) & 50 & 90 & 88 & * \\
\hline \multicolumn{5}{|c|}{ Mean change in DAS28 between } \\
\hline 0-2 Weeks & -1.3 & -1.2 & -1.1 & NS \\
\hline 2-6 Weeks & -0.4 & -0.7 & -1.0 & NS \\
\hline 6-14 Weeks & 0.9 & -0.1 & -0.2 & * \\
\hline 0-14 Weeks & $-0.9(-1.4)$ & $-2.0(-1.3)$ & $-2.4(-1.4)$ & * \\
\hline
\end{tabular}

*Indicates statistical significance, NS indicates no statistical significance.

\begin{tabular}{|c|c|c|c|c|}
\hline \multirow[b]{2}{*}{ Clinical response } & \multicolumn{3}{|c|}{ Pretreatment CRP levels } & \multirow[b]{2}{*}{ Significance } \\
\hline & $\begin{array}{l}\text { Low } \\
\text { (0-10 mg/l) }\end{array}$ & $\begin{array}{l}\text { Intermediate } \\
\text { (1 1-40 mg/l) }\end{array}$ & $\begin{array}{l}\text { High } \\
\text { (41-120 mg/l) }\end{array}$ & \\
\hline Mean DAS28, $t=0$ & 5.3 & 6.2 & 6.8 & NS \\
\hline Mean $C R P, t=0$ & 4 & 23 & 68 & * \\
\hline EULAR responders (\%) & 74 & 74 & 71 & NS \\
\hline \multicolumn{5}{|l|}{ Mean change in DAS28 } \\
\hline 0-14 Weeks & -1.6 & -2.0 & -1.6 & NS \\
\hline 0-2 Weeks & -0.9 & -1.3 & -1.5 & NS \\
\hline 2-6 Weeks & -0.5 & -0.9 & -0.6 & NS \\
\hline 6-14 Weeks & -0.2 & 0.2 & 0.6 & * \\
\hline Mean change in ESR $(\mathrm{mm} / 1 \mathrm{st}$ h) 6-14 weeks & -1 & 4 & 8 & * \\
\hline Mean change in $\mathrm{GH}(\mathrm{mm}) 6-14$ weeks & -5 & 5 & 15 & * \\
\hline Mean change in SJC 6-14 weeks & 0 & 0 & 3 & * \\
\hline Mean change in TJC 6-14 weeks & -1 & 0 & 3 & * \\
\hline
\end{tabular}

*Indicates statistical significance, NS indicates no statistical significance.

$\mathrm{GH}$, general health; SJC, swollen joint count; TJC, tender joint count.

and -2.4) than patients categorised as having intermediate or high serum trough infliximab levels. During the shorter dosing intervals the improvement of all three groups of patients was similar. However, during the 8 week dosing interval patients with low serum trough infliximab levels at 14 weeks had an increase in mean disease activity while patients with intermediate and high serum trough infliximab levels at 14 weeks showed further improvement in mean DAS28 score $(+0.9 v-0.1$ and -0.2$)$.

Pretreatment CRP levels, serum infliximab levels, and clinical improvement

CRP levels before treatment were used as an indirect marker for TNF production. Pretreatment CRP levels negatively

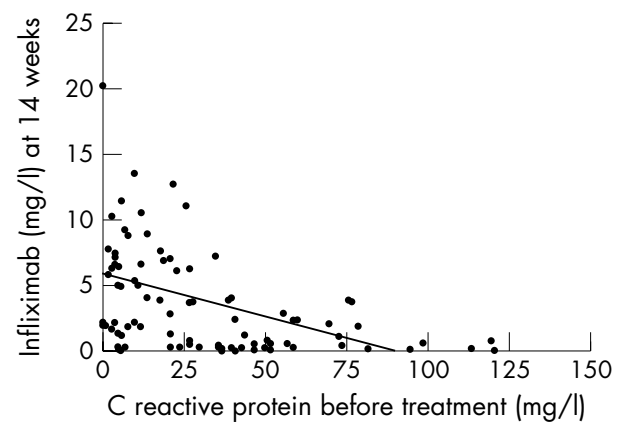

Figure 4 Correlation between serum trough infliximab levels at 14 weeks and CRP values before treatment in patients with RA treated with infliximab. correlated with serum infliximab levels at 2 weeks $\left(r_{\mathrm{s}}=-0.34, \mathrm{p}<0.001\right), 6$ weeks $\left(r_{\mathrm{s}}=-0.46, \mathrm{p}<0.001\right)$, and 14 weeks $\left(r_{\mathrm{s}}=-0.43, \mathrm{p}<0.001\right)$ (fig 4$)$. To investigate the relationship between pretreatment CRP levels and clinical response we categorised patients into three groups according to their pretreatment CRP level and compared the improvement in DAS28 score. Patients with low $(0-10 \mathrm{mg} / \mathrm{l})$ intermediate ( $11-40 \mathrm{mg} / \mathrm{l}$ ), and high (41-120 mg/l) pretreatment CRP levels had a similar improvement in DAS28 score from 0 to 14 weeks. Moreover the number of EULAR responders was the same for all three groups. During the 8 week treatment interval, however, the change in the DAS28 score of patients with low pretreatment CRP levels significantly differed from that of patients with high pretreatment CRP values $(-0.2(0.6) v 0.6(1.3), \mathrm{p}=0.01)$. This was seen for all individual factors which comprise the DAS28 (table 2).

\section{DISCUSSION}

We developed an assay for the detection of infliximab in the serum samples of patients and used this ELISA to investigate the relationship between serum trough infliximab levels and clinical response in a large cohort of patients with RA treated with the standard regimen of $3 \mathrm{mg} / \mathrm{kg}$ infliximab. We show that serum trough levels of infliximab after 14 weeks of treatment according to this regimen are higher in responders than in non-responders. In addition, patients with low serum trough infliximab levels have less improvement in the DAS28 score. Interestingly, we also observed a correlation between pretreatment CRP and serum infliximab levels and found that serum infliximab was undetectable before infliximab infusions that induce an allergic response. 
Based on the results of the ATTRACT study most patients with RA are treated with $3 \mathrm{mg} / \mathrm{kg}$ of infliximab every 8 weeks. In clinical practice many patients treated with infliximab do not reach clinical remission. Many of these patients are treated with higher dosages of infliximab. Of interest, the ATTRACT study shows a tendency for the lower doses to be less effective than the higher doses. A post hoc analysis of this study suggested a relationship between clinical response and serum infliximab levels. ${ }^{5}$ Two recent studies showed an effect of dose escalation in patients with insufficient response. This effect was, however, only limited and might be explained by regression to the mean. Our study confirms the relationship between clinical response and serum through infliximab levels as shown by St Clair et al $l^{5}$ and extends these observations. As infliximab is expensive it might be efficient to adjust the infliximab dosing schedule after measurement of the serum infliximab concentration.

We used pretreatment CRP levels as an indirect marker of TNF production. We observed a correlation between pretreatment CRP levels, serum trough infliximab levels, and clinical response. Higher levels of TNF production in patients with high CRP levels might explain this relationship. Furthermore, it is possible that infliximab-TNF complexes are cleared from the circulation at a faster rate than unbound infliximab. The clinical implication of this finding is that patients with high pretreatment CRP levels might benefit more from higher dosages of infliximab than patients with low pretreatment CRP levels.

The chimerical antibody infliximab may induce infusion related allergic reactions, which are associated with the formation of anti-infliximab antibodies. ${ }^{20}$ In all three patients with a clinically overt infusion reaction serum concentrations of infliximab before the infusion that elicited the reaction were below the detection limit of our assay. This could be due to the binding of infliximab by immune complexes or by anti-infliximab antibodies.

Despite treatment with infliximab infusions many patients with RA still have persistent disease activity. The response to infliximab treatment is related to serum infliximab levels and shows a large variation between patients. Further investigation into the mechanisms that determine serum concentrations of infliximab may help to optimise this treatment.
Authors' affiliations

G J Wolbink, B A C Dijkmans, Jan van Breemen Institute, Amsterdam, The Netherlands

A E Voskuyl, W F Lems, B A C Dijkmans, VU Medical Centre, Amsterdam, The Netherlands

W F Lems, B A C Dijkmans, Slotervaart Hospital, Amsterdam, The Netherlands

G J Wolbink, E de Groot, M T Nurmohamed, L Aarden, Sanquin

Research, Amsterdam, The Netherlands

P P Tak, Academic Medical Centre/University of Amsterdam,

Amsterdam, The Netherlands

\section{REFERENCES}

1 Maini R, St Clair EW, Breedveld F, Furst D, Kalden J, Weisman M, et al. the ATTRACT Study Group. Infliximab (chimeric anti-tumour necrosis factor alpha monoclonal antibody) versus placebo in rheumatoid arthritis patients receiving concomitant methotrexate: a randomised phase III trial, Lancet 1999:354:1932-9.

2 Maini RN, Breedveld FC, Kalden JR, Smolen JS, Davis D, Macfarlane JD, et al. efficacy of multiple intravenous infusions of anti-tumor necrosis factor alpha monoclonal antibody combined with low-dose weekly methotrexate in rheumatoid arthritis. Arthritis Rheum 1998;41:1552-63.

3 Fitzcharles MA, Clayton D, Menard HA. The use of infliximab in academic rheumatology practice: an audit of early clinical experience. J Rheumatol 2002;29:2525-30.

4 Smolen J, Breedveld F, Burmester G, Combe B, Emery P, Kalden J, et al. Consensus statement on the initiation and continuation of TNF blocking therapies in rheumatoid arthritis. Ann Rheum Dis 2000;59:504-5.

5 StClair EW, Wagner CL, Fasanmade AA, Wang B, Schaible, Kavanaugh A et al. The relationship of serum infliximab concentrations to clinical improvement in rheumatoid arthritis. Arthritis Rheum 2002;46:1451-9.

6 Sidiropoulos P, Bertsias G, Kritikos HD, Kouroumali H, Voudouris K, Boumpas DT. Infliximab treatment for rheumatoid arthritis, with dose titration based on the Disease Activity Score: dose adjustments are common but not always sufficient to assure sustained benefit. Ann Rheum Dis 2004;63:144-8.

7 van Vollenhoven RF, Brannemark S, Klareskog L. Dose escalation of infliximab in clinical practice: improvements seen may be explained by a regression-like effect. Ann Rheum Dis 2004;63:426-30.

8 Arnett FC, Edworthy SM, Bloch DA, McShane DJ, Fries JF, Cooper NS, et al. The American Rheumatism Association 1987 revised criteria for the classification of rheumatoid arthritis. Arthritis Rheum 1988;31:315-24.

9 Prevoo MLL, van 't Hof MA, Kuper HH, van Leeuwen MA, van de Putte LBA, van Riel PLCM. Modified disease activity scores that include twenty-eight-joint counts: development and validation in a prospective longitudinal study of patients with rheumatoid arthritis. Arthritis Rheum 1995:38:44-8.

10 Baert F, Noman M, Vermeire S, Van Assche G, D' Haens G, Carbonez A, et al. Influence of immunogenicity on the long-term efficacy of infliximab in Crohn's Disease. N Engl J Med 2003;348:601-8. 